\title{
Performance of Propargyl Alcohol as Corrosion Inhibitor for Electroless Nickel- Phosphorus (NiP) Coating in Hydrochloric Acid Solution
}

Fernando B. Mainier*, Thiago Theobaldo da Silva and Fabio P. D. de Araujo

Escola de Engenharia, Universidade Federal Fluminense , Niterói, Rio de Janeiro, Brazil

*Corresponding Author Email: fmainier@uol.com.br

\begin{abstract}
The electroless nickel-phosphorus (NiP) coatings have been used with great success in oil production equipment and accessories, such as pipes, valves, pumps, adapters, rings, connectors and various types of special tools. In the acidification or acid stimulation of oil wells, to increase their productivity, a hydrochloric acid ( $\mathrm{HCl}$ ) solution is preferably injected from concentrations of 5 to $28 \%$, aiming at the dissolution of a reservoir rock constituted of limestone and dolomite. In addition, the HCl solutions are also used to remove lime scale adhering to carbon steel pipes, where propargyl alcohol as a corrosion inhibitor, has shown good anticorrosion protection. The aim of this work is centred on the laboratory evaluation of NiP coating in 5\% and $10 \% \mathrm{HCl}$ solution, and addition of propargyl alcohol as a corrosion inhibitor. The mass loss and polarisation curves proved to be very promising with propargyl alcohol as a corrosion inhibitor.
\end{abstract}

Keywords: Electroless NiP coating, propargyl alcohol, corrosion inhibitor, hydrochloric acid, acid stimulation Received: October-26-2020, Accepted: November-18-2020, https://doi.org/10.14447/jnmes.v24i1.a05

\section{INTRODUCTION}

The autocatalytic chemical deposition of nickel (Ni) and phosphorus (P) on carbon steel surface, without external current application, is performed by cathodic reduction with the atomic hydrogen $(\mathrm{H})$, from the hydrolysis of hypophosphite $\left(\mathrm{H}_{2} \mathrm{PO}_{2}{ }^{-}\right)$and nickel salts $\left(\mathrm{Ni}^{2+}\right)$, as shown in Figure 1.

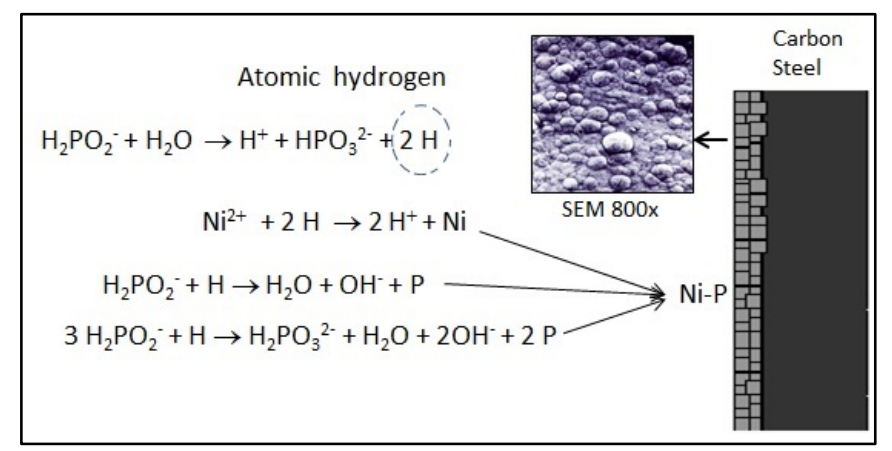

Figure 1. Scheme of formation of NiP coating and scanning electron microscopy (SEM) image with X 800

In addition, $\mathrm{pH}$ regulators, complexing agents and other additives are added to ensure a good adhesion of the NiP layer to the metal surface. The resistance to corrosion and abrasion of this coating depends on the content of $\mathrm{Ni}$ and $\mathrm{P}$ present in the layer deposited, and the increase of the $\mathrm{P}$ content favours the anticorrosive protection.

The co-deposition of NiP has the behaviour of a crystalline or amorphous alloy, which depends on the mass ratio of $\mathrm{Ni}$ and $\mathrm{P}$. For severe operating conditions, the $\mathrm{P}$ content must not be less than $10 \%$ by mass [1-6].

The justifications for the evaluation of $\mathrm{NiP}$ coating in the solutions of $\mathrm{HCl}$, with and without the addition of corrosion inhibitors, are based on the acid stimulation process, which consists of the injection of $\mathrm{HCl}$ in the limestone or dolomite reservoir rock to increase the productivity in oil and natural gas production $[7,8]$.

The $\mathrm{HCl}$ reacts easily with limestones $\left(\mathrm{CaCO}_{3}\right)$ or dolomites $\left(\mathrm{CaCO}_{3} \cdot \mathrm{MgCO}_{3}\right)$ by solubilizing the rocks in soluble chlorides $\left(\mathrm{CaCl}_{2}\right.$ and $\left.\mathrm{MgCl}_{2}\right)$ and carbon dioxide $\left(\mathrm{CO}_{2}\right)$, increasing permeation, not forming tampons or restrictions, and consequently increasing oil production.

The propargyl alcohol is a corrosion inhibitor, soluble in the acid medium that has been used in these petroleum operations with good performance, for both carbon steel and stainless steels [9 - 13].

\section{MATERIALS AND METHODS}

The rectangular coupons $(35.5 \mathrm{~mm} \times 15 \mathrm{~mm} \times 4 \mathrm{~mm})$ of mild steel were used as the substrate material for the preparation of electroless NiP coatings.

These coupons were immersed in a commercial acidic sodium hypophosphite bath, kept thermostatically at $90^{\circ} \mathrm{C}$, consisting basically of sodium hypophosphite, nickel chloride, complexing agents and $\mathrm{pH}$ regulating substances, to form a coating with $10.39 \%$ phosphorus and in the following NiP thicknesses: $10.37 \mu \mathrm{m}, 38.39 \mu \mathrm{m}$ and $67.40 \mu \mathrm{m}$.

The theoretical NiP mass of each coupon, in function of its thickness, can be determined by the following equation:

$\mathrm{m}=\rho$. S.e

where, $\mathrm{m}=$ mass of $\mathrm{NiP}$ coating $(\mathrm{g}), \mathrm{S}=$ surface area $\left(\mathrm{cm}^{2}\right)$, e $=\mathrm{NiP}$ thicknesses $(\mathrm{mm})$ and $\rho=$ density of NiP coating $(7.95$ $\mathrm{g} / \mathrm{cm}^{3}$ ), calculated on the basis of the work carried out by Parkinson [14] and Umapathi et al.[15].

On average, the theoretical $\mathrm{NiP}$ mass relative to the thicknesses of $10.37 \mu \mathrm{m}, 38.39 \mu \mathrm{m}$ and $67.40 \mu \mathrm{m}$ are $90 \mathrm{mg}$, $260 \mathrm{mg}$ and $570 \mathrm{mg}$, respectively.

The corrosive medium used in the tests was 5 to $10 \%$ (by volume) of high purity $\mathrm{HCl}$. The corrosion inhibitor used was 
98\% purity propargyl alcohol (2-Propyn-ol-1, $\mathrm{HC} \equiv \mathrm{CH}_{2}-\mathrm{OH}$ ) at concentrations of $0.63 \mathrm{mg} / \mathrm{L}, 1.25 \mathrm{mg} / \mathrm{L}$ and $1.86 \mathrm{mg} / \mathrm{L}$.

The coupons with electroless $\mathrm{Ni}-\mathrm{P}$ coatings to be used in the mass loss assays were washed with the running water, the oil was removed with acetone and ethyl alcohol, and dried with hot air and subsequently weighed.

The loss of NiP coating mass in the assays consisted essentially of placing the NiP coated coupons in the glass bottle containers, with a capacity of $100 \mathrm{~mL}$, where the specimens were completely immersed in the acid solutions with and without propargyl alcohol, and maintained at the test temperature in a thermostatic bath during the exposure time. The temperatures were maintained at $25^{\circ} \mathrm{C}$ and $60{ }^{\circ} \mathrm{C}$, while exposure times were $1 \mathrm{~h}$ and $4 \mathrm{~h}$.

Immediately after the completion of the assays, the coupons were removed from the corrosive medium, washed with distilled water and ethanol, dried with hot air and weighed with the same prior precision.

In the electrochemical polarisation tests, the coupons were made with $0.20 \mathrm{~cm}^{2}$ of exposed area and encapsulated in the polyester resin. The electrochemical cell test, with capacity of $200 \mathrm{~mL}$, consisted of a three-electrode arrangement: a saturated calomel reference electrode, a platinum plate as the counter electrode and the NiP coating sample as the working electrode.

The test was conducted on a Type III Autolab potentiostat, by varying the potentials at intervals of $60 \mathrm{mV} / \mathrm{min}$, over a range of $-300 \mathrm{mV}$ to $+300 \mathrm{mV}$, with respect to an open circuit potential by a desk top computer [10].

To avoid any possible attack of $\mathrm{HCl}$ on the carbon steel substrate, the NiP coating thickness was set at $67.40 \mu \mathrm{m}$, the temperature at $25{ }^{\circ} \mathrm{C}$, and propargyl alcohol additions at concentrations of $0.63 \mathrm{mg} / \mathrm{L}, 1.25 \mathrm{mg} / \mathrm{L}$ and $1.86 \mathrm{mg} / \mathrm{L}$ were fixed. Based on the polarisation curves, the polarisation resistance $\left(R_{p}\right)$ and the efficiency of the addition of the corrosion inhibitor (Effic \%) were determined.

\section{RESULTS AND DISCUSSION}

The mass of the carbon steel coupons is approximately 30 $35 \mathrm{~g}$, while according to the theoretical calculation, on average, for NiP coating thicknesses of $10.37 \mu \mathrm{m}, 38.39 \mu \mathrm{m}$ and $67.40 \mu \mathrm{m}$, the masses are $90 \mathrm{mg}, 260 \mathrm{mg}$ and $570 \mathrm{mg}$, respectively. Because of this discrepancy, between the total mass of the coupon and the reduced mass of the NiP coating, it was not possible to calculate the mass loss of the NiP coating with certainty, in relation to the attack of the $\mathrm{HCl}$ solution. This fact is based on the coupon metallography after the $\mathrm{HCl}$ tests.

The metallography of coupons with NiP thicknesses of $10.37 \mu \mathrm{m}$ and $38.39 \mu \mathrm{m}$, subjected to tests of $10 \% \mathrm{HCl}$ at $60{ }^{\circ} \mathrm{C}$ temperature and 4 hour immersion times, showed pitting and crevices leaving the carbon steel substrate exposed to $\mathrm{HCl}$ attack, as shown in Figures 2 and 3. However, for the NiP thickness of $67.40 \mu \mathrm{m}$, these failures were not observed, as shown in Figure 4.

A porous glass slide with a $49.5 \mu \mathrm{m} \mathrm{NiP}$ coating, was placed in a beaker containing $10 \% \mathrm{HCl}$, at $60{ }^{\circ} \mathrm{C}$ for $2 \mathrm{~h}$ to evaluate the etching of the acid to the NiP coating. After the end of the test, the dark residue was analysed by molecular absorption spectrometric method indicated by ISO 4527 [16] and revealed to be constituted of $10.31 \%$ phosphorus (P). Therefore, the expected reaction of $\mathrm{HCl}$ to $\mathrm{NiP}$ coating is:

$$
\mathrm{Ni}+2 \mathrm{HCl} \rightarrow \mathrm{NiCl}_{2}+\mathrm{H}_{2} \text {. }
$$

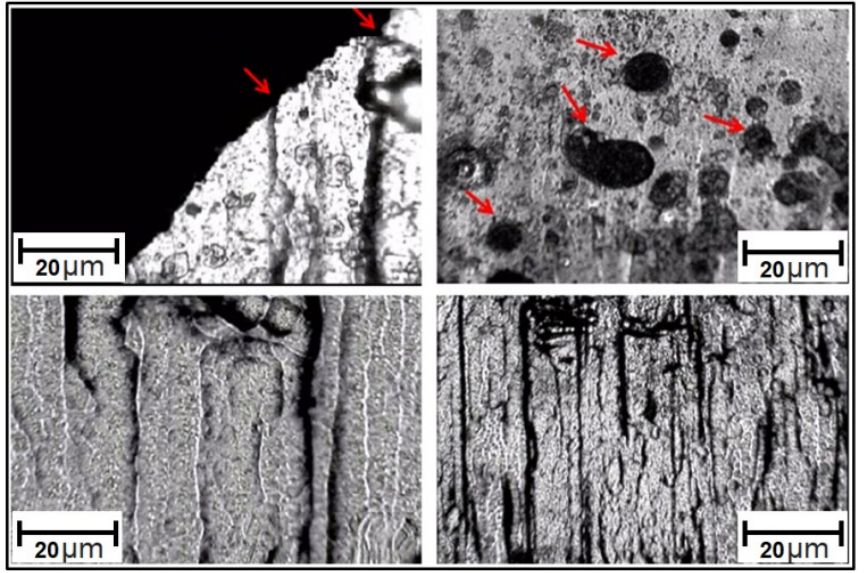

Figure 2. Aspects of the micrographics of the coating's surfaces of $\mathrm{NiP}$ with $10.37 \mu \mathrm{m}$ to the attack of $\mathrm{HCl}$ at $60{ }^{\circ} \mathrm{C}$ and $4 \mathrm{~h}$ of immersion.

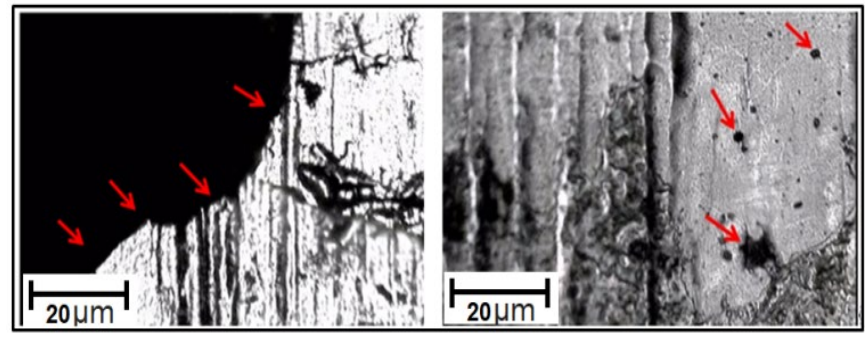

Figure 3. Aspects of the micrographics of the coating's surfaces of NiP with $38.39 \mu \mathrm{m}$ to the attack of $\mathrm{HCl}$ at $60^{\circ} \mathrm{C}$ and $4 \mathrm{~h}$ of immersion.

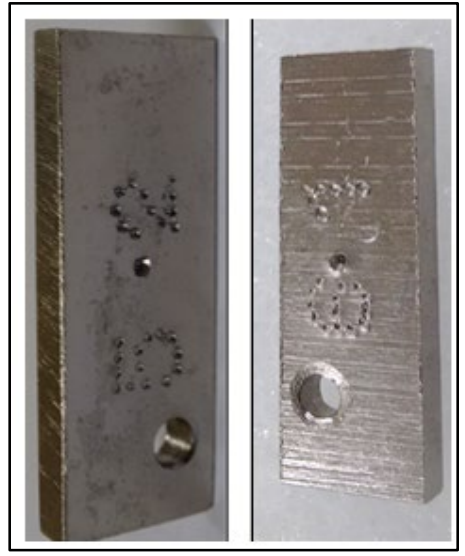

Figure 4. The NiP coupons with $67.40 \mu \mathrm{m}$ do not show partial destruction because of the attack of $\mathrm{HCl}$ at $60{ }^{\circ} \mathrm{C}$ and $4 \mathrm{~h}$ of immersion

The polarisation curves for electroless $\mathrm{NiP}$ coatings in $5 \%$ and $10 \%$ (by volume) $\mathrm{HCl}$ solutions, in the absence and presence of propargyl alcohol additions, at concentrations of $0.63 \mathrm{mg} / \mathrm{L}, 1.25 \mathrm{mg} / \mathrm{L}$ and $1.86 \mathrm{mg} / \mathrm{L}$ at $25{ }^{\circ} \mathrm{C}$, are shown in Figures 5 and 6. 


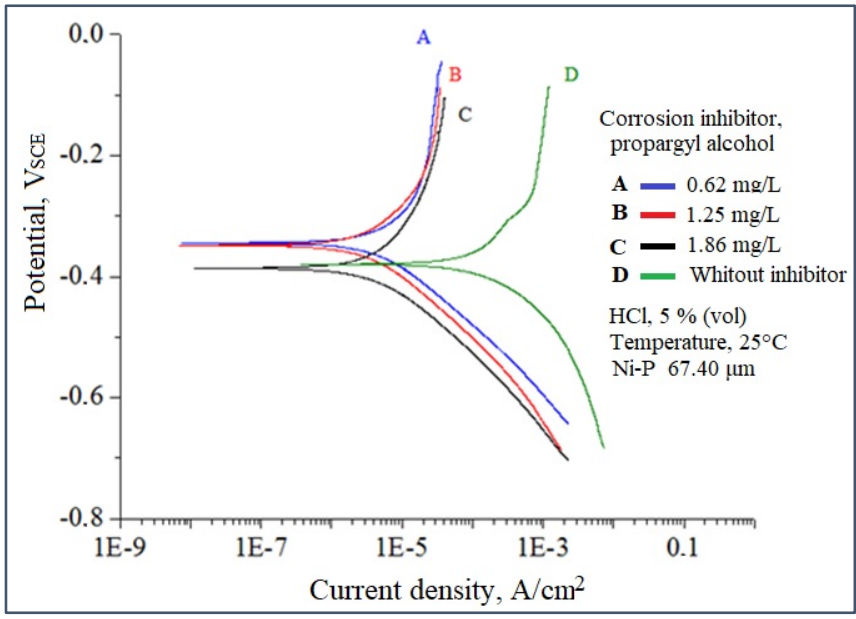

Figure 5. Polarisation curves of electroless NiP coatings with $67.40 \mu \mathrm{m}$ in $5 \% \mathrm{HCl}$ at the temperature of $25^{\circ} \mathrm{C}$.

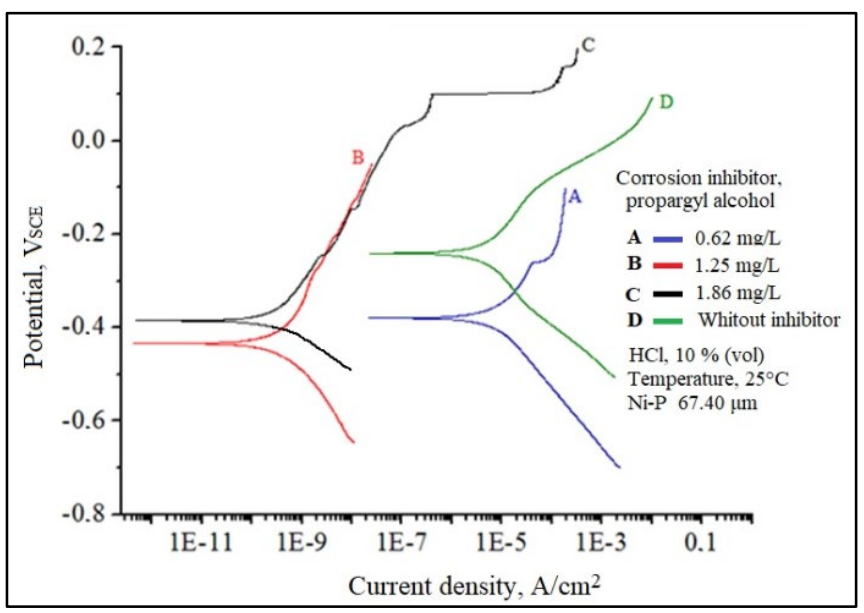

Figure 6. Polarisation curves of electroless NiP coatings with $67.40 \mu \mathrm{m}$ in $10 \% \mathrm{HCl}$ at the temperature of $25^{\circ} \mathrm{C}$.

The polarisation resistance $\left(\mathrm{R}_{\mathrm{p}}\right)$, the current density $\left(\mathrm{I}_{\mathrm{cor}}\right)$ and the corrosion potential $\left(\mathrm{E}_{\mathrm{cor}}\right)$ were determined based on the polarisation curves, and are shown in Tables 1 and 2. The following equation shows the inhibitor corrosion efficiency under the conditions tested:

$$
\text { Effic. } \%=100\left(I_{o}-I_{i n h i b} / I_{0}\right) \text {, }
$$

where, Effic. $\%=$ corrosion inhibitor efficiency; $\mathrm{I}_{\mathrm{o}}=$ current density without the addition of the corrosion inhibitor, and $\mathrm{I}_{\text {inhib }}=$ current density with the addition of the corrosion inhibitor.

Table 1. Electrochemical parameters of the polarisation curves of NiP coating in $5 \% \mathrm{HCl}$

\begin{tabular}{ccccc}
\hline $\begin{array}{c}\text { Corrosion } \\
\text { Inhibitor, } \mathbf{~ m g / L}\end{array}$ & $\begin{array}{c}\mathbf{I}_{\text {corr, }}, \\
\mathbf{A} / \mathbf{c m}^{2}\end{array}$ & $\begin{array}{c}\mathbf{E}_{\text {corr, }}, \\
\mathbf{V}\end{array}$ & $\begin{array}{c}\mathbf{R}_{\mathbf{p}}, \\
\mathbf{\Omega c m}^{2}\end{array}$ & $\begin{array}{c}\mathbf{E f f i c}, \\
\mathbf{\%}\end{array}$ \\
\hline 0 & $5.21 \times 10^{-3}$ & -0.379 & 166.94 & ----- \\
0.62 & $1.84 \times 10^{-3}$ & -0.344 & 801.26 & 79.25 \\
1.25 & $1.16 \times 10^{-3}$ & -0.348 & 1390.82 & 88.11 \\
1.86 & $2.64 \times 10^{-4}$ & -0.342 & 8333.33 & 99.79 \\
\hline
\end{tabular}

Table 2. Electrochemical parameters of the polarisation curves of $\mathrm{NiP}$ coating in $10 \% \mathrm{HCl}$

\begin{tabular}{ccccc}
\hline $\begin{array}{c}\text { Corrosion } \\
\text { Inhibitor, } \mathbf{m g} / \mathbf{L}\end{array}$ & $\begin{array}{c}\mathbf{I}_{\text {corr, }}, \\
\mathbf{A} / \mathbf{c m}^{\mathbf{2}}\end{array}$ & $\begin{array}{c}\mathbf{E}_{\text {corr, }}, \\
\mathbf{V}\end{array}$ & $\begin{array}{c}\mathbf{R}_{\mathbf{p}}, \\
\mathbf{\Omega c m}^{\mathbf{2}}\end{array}$ & $\begin{array}{c}\mathbf{E f f i c}, \\
\mathbf{\%}\end{array}$ \\
\hline 0 & $8.41 \times 10^{-2}$ & -0.240 & 149.70 & ---- \\
0.62 & $4.61 \times 10^{-3}$ & -0.379 & 540.64 & 72.30 \\
1.25 & $3.32 \times 10^{-3}$ & -0.434 & 1212.1 & 87.64 \\
1.86 & $3.01 \times 10^{-4}$ & -0.384 & 10764.2 & 98.60 \\
\hline
\end{tabular}

These polarisation curves (anodic and cathodic branches) show that the addition of propargyl alcohol to the $\mathrm{HCl}$ solution (5 and 10\%) causes these curves to move towards smaller currents. To a similar extent, the displacement may be the consequence of a barrier effect or the adsorption of a propargyl alcohol film formed on the surface of the metal.

The polarisation curves show a quantitative reduction in the anodic and cathodic currents in the presence of propargyl alcohol, in comparison to the values for the $\mathrm{HCl}$ solution, without the addition of the corrosion inhibitor. The increased concentration of the corrosion inhibitor in the acid solution indicates an increased protection of the NiP coating applied on the carbon steel.

The metallography shown in Figure 7, made before and after the electrochemical tests in $10 \% \mathrm{HCl}$ solution without the corrosion inhibitor, shows pitting on the surface of the NiP coating.

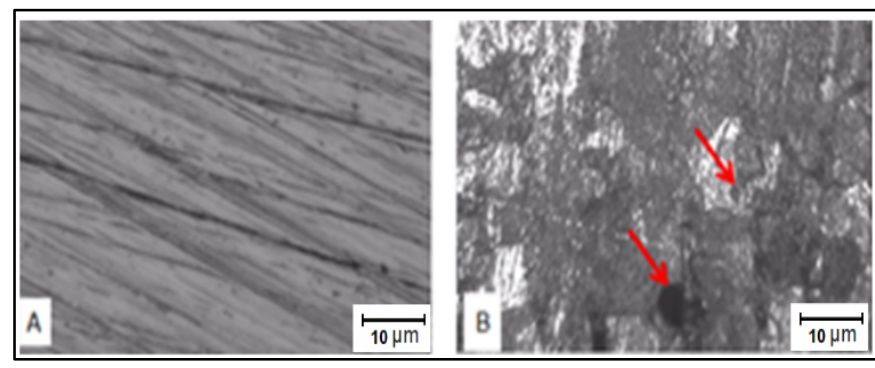

Figure 7. Micrograph of the NiP coating in $10 \% \mathrm{HCl}$ solution without the corrosion inhibitor. (A) - before the test; (B)- after the assay with the presence of pitting.

However, in Figure 8, in the same conditions, with the addition of propargyl alcohol, no pitting was detected. The addition of propargyl alcohol reduced the corrosive attack, when experiencing high concentrations of $\mathrm{HCl}$.

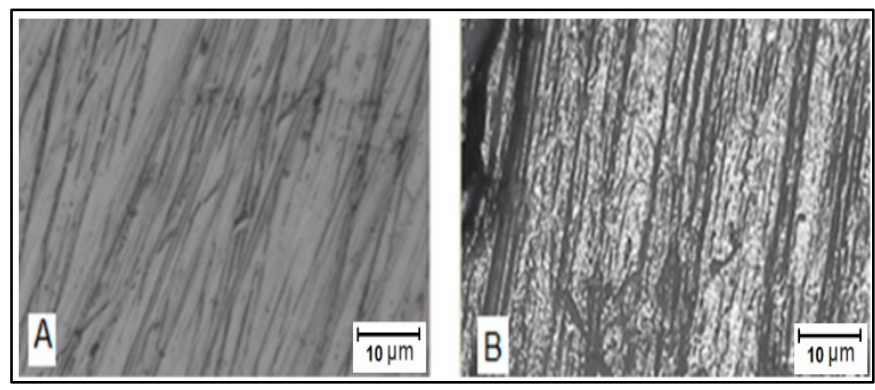

Figure 8. Micrograph of $\mathrm{NiP}$ coating in $10 \% \mathrm{HCl}$ solution with propargyl alcohol. (A) - before the test; (B)- after the assay without pitting. 


\section{PROPOSED CORROSION MECHANISM FOR NIP COATING IN HCI IN THE PRESENCE AND ABSENCE OF A CORROSION INHIBITOR}

Based on the investigations carried out by the authors $[9,17]$ with corrosion inhibitors, a mechanism is proposed to explain the corrosion and corrosion protection exerted by the propargyl alcohol in NiP coating, as shown in Figures 9 and 10. The anodic and cathodic reactions occurring in the NiP layer, and the competition between the migration of $\mathrm{H}^{+}$ions and the adsorption of propargyl alcohol, are divided into three steps.

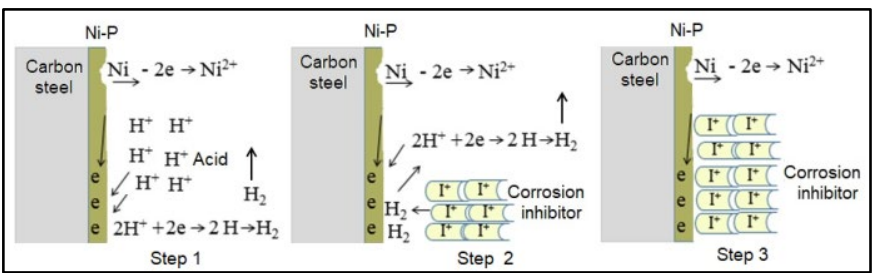

Figure 9. Proposed mechanism to explain both the corrosion and protection exerted by the corrosion inhibitor in an acidic environment.

In step 1, the $\mathrm{HCl}$ in contact with $\mathrm{NiP}$ coating, forms the $\mathrm{Ni}^{2+}$ ions that migrate to the solution, and simultaneously the $\mathrm{H}^{+}$ions migrate to the cathodic area of the coating forming the atomic hydrogen $(\mathrm{H})$, and then the molecular hydrogen $\left(\mathrm{H}_{2}\right)$ follows, according to the reactions, but phosphorus $(\mathrm{P})$ does not react with acid.

$$
\begin{aligned}
& \mathrm{Ni}-2 \mathrm{e} \rightarrow \mathrm{Ni}^{2+} \text { (anodic reaction) } \\
& 2 \mathrm{H}^{+}+2 \mathrm{e} \rightarrow 2 \mathrm{H} \rightarrow \mathrm{H}_{2} \text { (cathodic reaction). }
\end{aligned}
$$

From the moment, the inhibitor is added (step 2), the protonation process begins, which consists of the total or partial reaction of the $\mathrm{H}^{+}$ions with the propargyl alcohol molecules. A stable adsorption occurring on the surface of the coating of NiP forms a barrier, represented by step 3, that avoids or delays the $\mathrm{H}^{+}$ions' approach to capture electrons from the cathode surface.

The protonation of propargyl alcohol in hydrochloric acid explains its ability to acquire positive charges and from this shift to cathodic areas, consequently, reducing the possible anodic reactions of dissolution of iron and nickel on the metal surface [18-21].

The existence of pitting, voids, imperfections or defects in the NiP coating may cause direct contact of the $\mathrm{HCl}$ with the substrate (carbon steel), causing damage and acceleration of the corrosive process, as can be observed in the mechanism below showed in Figure 10.

In this case, step $3 \mathrm{a}$ shows the carbon steel $(\mathrm{Fe})$ attacked by the acid through the coating failure, forming the $\mathrm{Fe}^{2+}$ ions that migrate to the solution, while the $\mathrm{H}^{+}$ions follow the same path previously presented in the cathodic reaction, i.e. forming hydrogen atoms $(\mathrm{H})$ and then $\mathrm{H}_{2}$.

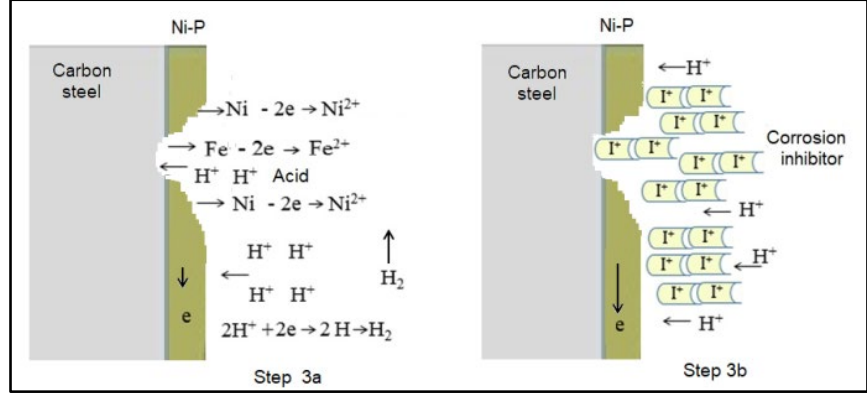

Figure 10. Proposed mechanism to explain both the corrosion and protection exerted by the corrosion inhibitor in an acidic environment when the carbon steel is attacked.

$\mathrm{Fe}-2 \mathrm{e} \rightarrow \mathrm{Fe}^{2+}$ (anodic reaction)

$2 \mathrm{H}^{+}+2 \mathrm{e} \rightarrow 2 \mathrm{H} \rightarrow \mathrm{H}_{2}$ (cathodic reaction).

In this case, the same inhibitor present in the solution will form a barrier that will avoid the anodic reactions (step 3b), which will prevent $\mathrm{H}^{+}$ions from capturing electrons. Thus, again the inhibitor migrates to the cathode areas (either coating or carbon steel), forming a barrier that prevents or retards acid reactions. It is important to emphasise the possibility of the galvanic corrosion effect, considering the galvanic pair (NiP)-Fe (carbon steel), where NiP acts as cathode and iron as anode.

\section{CONCLUSIONS}

On the basis of laboratory tests carried out, it is concluded that:

- Based on the NiP coating (containing $10.39 \%$ P) with the thicknesses of $10.37 \mu \mathrm{m}, 38.39 \mu \mathrm{m}$ and $67.40 \mu \mathrm{m}$ (thickness used in the tests), it was found that the loss of NiP mass is directly associated with the increase of temperature, hydrochloric acid concentration and immersion time.

- The thicknesses of $10.37 \mu \mathrm{m}$ and $38.39 \mu \mathrm{m}$ do not guarantee the carbon steel substrate, when immersed in $\mathrm{HCl}$ solutions at temperatures of $60^{\circ} \mathrm{C}$.

- The microscopic analysis showed that the pitting formed during the acid attack are risky, because they can be passed considering the thickness of the coating, i.e. the smaller the thickness the greater the possibility of these faults.

- The curves obtained in the polarisation of the specimens of the NiP coating with $67.40 \mu \mathrm{m}$, showed a shift of the curves from right to left, on the axis of the applied current intensity ( $\mathrm{I}_{\text {corr, }}$, as there is a greater addition of the propargyl alcohol. It is then accepted that, increasing the concentration of the corrosion inhibitor creates a resistance to the passage of the electric current, thereby reducing the corrosion of NiP coating.

- The protective efficiency of the NiP coating increases with the increasing concentration of the corrosion inhibitor. 
- Considering the good anti-corrosion performance, propargyl alcohol (Prop-2-in-1-ol) is an important corrosion inhibitor for $\mathrm{HCl}$ stimulation, and when associated with NiP coating, it can guarantee a longer life for equipment, connections and accessories used in the oil exploration.

\section{REFERENCES}

[1] Mainier, F. B. , Fonseca, M. P. C. , Tavares S. S. M. and Pardal, J. P. (2017). Quality of electroless Ni-P (nickel-phosphorus) coatings applied in oil production equipment with salinity. Journal of Materials Science and Chemical Engineering, 1 (6), 1-8. http://dx.doi.org/10.4236/msce.2013.16001.

[2] Fayyad, E. M., Abdullah, A. M., Hassan, M. K., Mohamed, A. M., Jarjoura, G., and Farhat, Z. (2018). Recent advances in electroless-plated Ni-P and its composites for erosion and corrosion applications: a review. Emergent Materials, 1 (1-2), 3-24. https://doi.org/10.1007/s42247-018-0010-4.

[3] Cui, G., Li, N., Li, D., Zheng, J., \& Wu, Q. (2006). The physical and electrochemical properties of electroless deposited nickel-phosphorus black coatings. Surface and Coatings Technology, 200(24), 6808-6814. https://doi.org /10.1016/j.surfcoat.2005.10.015.

[4] Krishnan, K. H., John, S., Srinivasan, K. N., Praveen, J., Ganesan, M., \& Kavimani, P. M. (2006). An overall aspect of electroless Ni-P depositions - A review article. Metallurgical and Materials Transactions A, 37(6), 1917-1926. https://doi.org/10.1007/s11661006-0134-7.

[5] Taheri, R., Oguocha, I. N. A., \& Yannacopoulos, S. (2005). Microstructure characterization of electroless NiP alloys. Canadian metallurgical quarterly, 44(1), 1321. https://doi.org/10.1179/cmq.2005.44.1.13.

[6] Gunaselvi, S., Satheeshkumar, P. and Jeganathan, M. (2020) Surface Modification of Steel by Nickel Coating in Electrochemical Process, Journal New Materials Electrochemical Systems, Vol. 23, No.2, April, pp. 112122. https://doi.org/10.14447/jnmes.v23i2.a08.

[7] Fink, J.K. (2003). Oil field chemicals, New York: Gulf Professional Publishing.

[8] Kalfayan, L. (2008). Production enhancement with acid stimulation. Pennwell Corp., Tulsa, Oklahoma, USA.

[9] Finšgar, M., Jackson, J., (2014). Application of corrosion inhibitors for steels in acidic media for the oil and gas industry: A review. Corrosion Science, 86, 1741. https://doi.org/10.1016/j.corsci.2014.04.044.

[10] Mainier, F. B., Farneze, H. N., Serrão, L. F. Oliveira, B. T. and Nani, B. F., (2018). Performance of Stainless Steel AISI 317L in Hydrochloric Acid with the Addition of Propargyl Alcohol. International Journal. Electrochemical Science, 13 (4), 3372-3381, https://doi.org/10.20964/2018.04.02.
[11] Avdeev, Y. G. (2018). Nitrogen-containing sixmembered heterocyclic compounds as corrosion inhibitors for metals in solutions of mineral acids-A review. International Journal of Corrosion and Scale Inhibition, 7(4), 460-497. doi: 10.17675/2305-68942018-7-4-1.

[12] Nascimento, R. C., Furtado, L. B., Guimarães, M. J. O., Seidl, P. R., Rocha, J. C., Ponciano, J. A. C., \& Cruz, M. T. M. (2018). Synergistic effect of propargyl alcohol, octadecylamine, and 1, 3-dibutyl thiourea for API P110 alloys in acetic and formic acidic solutions used in oil well acidizing. Journal of Molecular Liquids, 256,548557. https://doi.org/10.1016/j.molliq.2018.02.082.

[13] Mainier, F. B., dos Reis, V. P., de Barros, E. F., \& de Almeida, B. B. (2020). Evaluation of Propargyl Alcohol as a Corrosion Inhibitor for Duplex Stainless Steel in Hydrochloric Acid. Journal of Civil Engineering and Architecture, 14, 378-384. https://doi: 10.17265/19347359/2020.07.004.

[14] Parkinson, R. (1997). Properties and applications of electroless nickel. Nickel Development Institute, 37.

[15] Umapathi, D., Devaraju, A., Rathinasuriyan, C., \& Raji, A. (2020). Mechanical and tribological properties of electroless nickel phosphorous and nickel PhosphorousTitanium nitride coating. Materials Today: Proceedings, 22,1038-1042.

https://doi.org/10.1016/j.matpr.2019.11.283.

[16] ISO 4527 (2003). International Organization for Standardization. Metallic coatings: autocatalytic (electroless) nickel phosphorus alloy coatings: specification and test methods.

[17] Mainier, F. B., \& e Silva, R. D. M. B. (2015). Evaluation of corrosion inhibitors in acid medium. AntiCorrosion Methods and Materials, 62(4), 241-245, https://doi.org/10.1108/ACMM-12-2013-1329.

[18] Bartos, M., \& Hackerman, N. (1992). A study of inhibition action of propargyl alcohol during anodic dissolution of iron in hydrochloric acid. Journal of the Electrochemical Society, 139 (12), 3428-3433.

[19] Feng, Y., K. Siow, K. S., Teo, W. K. and A. K. Hsieh, A. K. (1999). The synergistic effects of propargyl alcohol and potassium iodide on the inhibition of mild steel in $0.5 \mathrm{M}$ sulfuric acid solution. Corrosion Science, 41(5), 829-852. https://doi.org/10.1016/S0010938X(98)0014.

[20] Jayaperumal, D. (2010). Effects of alcohol-based inhibitors on corrosion of mild steel in hydrochloric acid. Materials Chemistry and Physics, 119(3), 478-484. https://doi.org/10.1016/j.matchemphys.2009.09.028.

[21] Finšgar, M., \& Jackson, J. (2016). Electrochemical Study of AISI C1018 Steel in Methanesulfonic Acid Containing an Acetylenic Alcohol-Based Corrosion Inhibitor Formulation. Journal of laboratory automation, 21(5),632-641. https://doi.org/10.1177/2211068215593376. 